giéndolo, subraya el sentido de conservación que ha de procurarse antes de cometido el daño. De ahí la relación de «schonen» con «das Freie» (lo libre); si bien el cuidar tiende a quedar ligado con un daño ya ejecutado, el preservar permite pensar aquella disposición que antecede a todo daño, previniéndolo $-\mathrm{y}$ no solo, o no meramente, enfrentándolo-.

\section{Consideraciones finales}

En virtud de los análisis anteriormente dados, consideramos que la traducción de J. Adrián Escudero presenta una serie de sutilezas conceptuales que, contrastando con el resto de traducciones ofrecidas, han de tenerse en cuenta a la hora de discernir el horizonte hermenéutico que Heidegger traza en su conferencia. Si bien, tal y como hemos visto, las diferencias en la traducción son menores en lo que concierne a la propuesta de Eustaquio Barjau, cabe subrayar una ventaja fundamental: la edición bilingüe.

He aquí el último apunte que nos gustaría resaltar, constituyendo para nosotros uno de los aspectos que otorgan mayor peso a la traducción elaborada por J. Adrián: la posibilidad de realizar una lectura simultánea del texto en alemán y en español, la cual facilita al lector su tarea toda vez que garantiza el buen uso de los términos empleados. En contraste con la edición bilingüe de A. C. Gebhardt, la traducción simultánea que por escrito J. Adrián nos ofrece tiene la fortuna de apoyarse en las recientes e inéditas publicaciones que nos llegan desde Alemania. Téngase en cuenta que son cuarenta y tres los años que distancian la edición bilingüe de Gebhardt (1977) de la actual (2015); distancia que hace que esta última adquiera una panorámica más amplia de la obra completa (Gesamtausgabe) de Heidegger.

En razón, justamente, de los sucesivos textos que han ido saliendo a la luz en las últimas décadas, la necesidad de elaborar una edición bilingüe de la mano de especialistas en la obra del autor se tornaba cada vez más acuciante. A nuestro entender, la traducción de Adrián y la edición bilingüe que la acoge se encuentran a la altura de la circunstancia que supone la obra de Heidegger en nuestros días. Esperando, con todo, que las cuestiones planteadas anteriormente hayan podido suscitar el interés del lector, remitimos al mismo a ir más allá de ellas -las cuales son tan solo un esbozo de los principales ejes que articulan la problemática de la traducción de un texto del pensador alemán-: invitados quedan todos, pues, a valorar por sí mismos la edición presentada.

Jezabel Rodríguez Pérez

http://dx.doi.org/10.6018/289681

KANT, Immanuel (2016): Lecciones de Filosofía Moral Mrongovius II. Salamanca: Sígueme. Edición bilingüe de Alba Jiménez. 155 pp.

Esta edición de las transcripciones de las lecciones de filosofía moral de Kant realizadas por su alumno polaco Kryzystof Celestyn Mrongovius en el invierno de 1784-1785, también conocidas como Moral Mrongovius II, supone una contribución fundamental a la hora de dilucidar las claves de comprensión dentro de las cuales se gestó la redacción de Fundamentación de la Metafísica de las Costumbres, cuya publicación tuvo lugar el mismo año que las lecciones. Además de por su aporte revelador de vertientes 
comprensivas de la Grundlegung distintas a las de otras versiones de las lecciones de filosofía moral de Kant, la presente edición posee un genuino valor por sí misma al poner al alcance del lector la exposición en estilo oral y directo de planteamientos medulares del pensamiento kantiano.

La edición bilingüe alemán-español a cargo de la profesora Alba Jimenez tiene el valor añadido de facilitar al lector conocedor de ambas lenguas una lectura simultánea de sendos textos, permitiéndole saltar ágilmente de uno a otro con el fin de afinar la aprehensión de los conceptos y participar al mismo tiempo en el juego de múltiples mediaciones que en las lecciones se plasman. Porque como la propia editora resalta en su esclarecedor estudio conclusivo, el texto que se abre al lector es «el resultado de un entrelazamiento de particular tejido en que se entreveran infinitas mediaciones de mediaciones». Mediación del propio alumno al pasar por escrito las palabras de Kant, mediación de su condición no germano parlante, mediación del manual de Baumgarten del que Kant ha de servirse y desde y contra él cual dicta sus clases. Semejante juego de mediaciones hace de la decisión de la editorial Sígueme de publicarlas en edición bilingüe una contribución tanto más enriquecedora. En el citado estudio conclusivo la profesora Alba Jiménez se refiere a la metáfora del taller utilizada en el campo de la Kant-Forschung para describir este tipo de fuentes. Digamos en este sentido que el aparato de notas y aclaraciones terminológicas que jalona esta edición de los apuntes del estudiante de Kant, K.C. Mrongovius, son una magnífica «caja de herramientas» para todo lector que quiera penetrar en el carácter vivo y móvil que en ellos presentan las doctrinas kantianas.

Este carácter vivo y móvil se refleja tanto en la fluidez con que surgen los temas que a Kant más importan para su idea de filosofía moral, como en el ritmo uniforme que, a modo de artesano en su torno, el profesor Kant va imprimiendo a su magisterio y gracias al cual el maestro consigue, en un primer momento, realzar los contornos de su imperativo sobre el trasfondo de polémicos y vivaces diálogos con las teorías morales de otros para, en un segundo momento- dotado su imperativo ya de categórico relieve- cincelar las consecuencias que se derivan de los tres ámbitos que su labor docente ha ido extrayendo de la piedra filosófica inicial: el ámbito de la necessitas (Notwendigkeit) o voluntad santa, el de la necesitación práctica (Nötigung)- imputación o causa libre y el de la necesitación patológica o causalidad natural.

Casi desde el principio de Moral Mrongovius II Kant nos confronta con una pregunta clave: «¿Puede conocerse algo a priori?»y unos renglones más abajo queda ya dibujada una distinción fundamental entre moral y filosofía práctica universal. Si a la primera la conforman las reglas a priori de acuerdo a las cuales debe determinarse la voluntad, a la segunda lo hacen las reglas por las que la voluntad se determina a posteriori. En diálogo polémico con Baumgarten y Wolff a propósito de la noción de deber, Kant utiliza el término «Bewegungsgrund» que junto con el de «Triebfeder» prefigura un par terminológico de compleja traducción presente también en la Grundlegung y en otros pasajes de la obra de Kant. En general, la oposición entre principios de inteligibilidad referidos a lo sensible y a lo inteligible, a lo fenoménico y a lo nouménico, al orden del ser y al del deber ser, «no solo abre» en palabras de la editora, «un campo de problemas común a los formulados en la Fundamentación de la metafísica de las costumbres, a veces como anticipación de algunas de las claves de lectura de la Metafísica de las Costumbres, sino 
que funciona como un horizonte de comprensión que permite articular algo así como una unidad de sentido.» Unidad de sentido que coincide con una de las preocupaciones básicas de la filosofía desde sus comienzos.

Esta unidad de sentido se articula en las lecciones en primera instancia en la respuesta de Kant a la cuestión sobre la necesidad de las acciones. Para Kant esta necesidad radica no en la importancia de los motivos que las originan, como Baumgarten y Wollf sostienen, sino en el origen de estos motivos, en si los motivos para la acción provienen de las inclinaciones o de la razón. «Toda fórmula» nos dice Kant «que dice que mi acción es necesaria de acuerdo con la razón es un imperativo». Tres son los imperativos que Kant nos propone pensar: 1.-el imperativo de habilidad, por el que debe hacerse algo si quiere lograrse un fin, es decir, la ciencia de los medios 2.-el imperativo de prudencia por el que debe hacerse algo si lo que se quiere es la felicidad en tanto fin a posteriori representado por el máximo grado de satisfacción de las inclinaciones 3.-el imperativo de moralidad por el que la razón que fundamenta la necesidad de la acción es depurada de las inclinaciones. Este último imperativo constituye una moralia pura que nos indica que debe hacerse algo sin condición y sin excepción y que viene a ser a la philosofia moralis applicata o ética lo que la metafísica a la física.

En segundo lugar, Kant delimita, aquilata y completa la cualidad de esta moralia pura entrando a fondo en ese diálogo vivaz con otros autores antes mencionado, ganando el terreno de fundamentación de su moral a partir de los infructuosos intentos llevados a cabo por otros. Así, por un lado, la mera remisión del bien supremo a la virtud de la persona de los estoicos adolecería de una falta de realismo ajena a la verdadera naturaleza humana dado que el hombre, si bien potencialmente consciente de la más alta virtud, padece los males y aflicciones de su estado físico y no puede permanecer indiferente a ellos como los estoicos querrían. Por otro lado, el máximo valor que por su parte los epicúreos otorgan al estado de felicidad- bienestar de la persona- estaría haciendo depender su noción de bien supremo de causas externas y accidentales ligadas a la sensibilidad y no a la voluntad («Das Wohl» oder «das Übel» como bien y mal físicos frente a «das Güte» oder «das Böse» como bien y mal morales dependientes de la voluntad). Junto a estoicos y epicúreos, el ideal negativo de bien supremo de los cínicos sería una suerte de virtud de la ausencia de virtud por la que al hombre le bastaría con no corromper su estado de naturaleza para ser virtuoso; un ideal, este de la inocencia de la secta de Diógenes, que será retomado más tarde igualmente en vano por Rousseau por tratarse de un tipo de ideal que no puede darse en la experiencia ni ser representado como un individuum, (así la singularidad de los ideales frente a la universalidad de las ideas, cuyos objetos no pueden ser expuestos in concreto). A estoicos, epicúreos y cínicos corresponderían respectivamente tres ideales de hombre perfecto: el sabio, el hombre de mundo y el hombre de la naturaleza. A esta lista cabría añadir el ideal del místico de Platón, que se elevaría a la perfección de las ideas tal y como las contempla la divinidad. En los cuatro casos, los antiguos habrían pretendido unir bienestar y virtud, bien físico y bien moral, valor del estado y valor de la persona, ser y deber ser, fenómeno y noúmeno, pero lo habrían hecho sin la religión, que es, a juicio del Kant de estas lecciones, justamente lo único que posibilita la felicidad (estado) a quien se ha hecho digno de ella (comportamiento). Pero es que además 
la pretensión de los antiguos de derivar la felicidad de la virtud y la virtud de la felicidad es algo imposible. Como la profesora Alba Jiménez recoge a este respecto, a diferencia de la conexión analítica entre virtud y felicidad de estoicos y epicúreos (bien derivable la una de la otra, bien reducible la una a la otra), «la conexión entre virtud y felicidad es para Kant de carácter sintético a priori presentándose la felicidad como una consecuencia, ya en el mundo fenoménico, de la conducta virtuosa del sujeto nouménico».

Abundando en este diálogo con los antiguos, prolongado, como se ve, hasta sus contemporáneos, Kant sostiene que aquellos tampoco fueron capaces de distinguir entre los principios objetivos de la moral y los subjetivos. Los primeros corresponderían a las leyes de la moralidad, los segundos a las máximas conforme a las cuales actuamos, al «cómo»-antropológico- deben obedecerse estas leyes objetivas, las causas naturales, en suma, de acceso a la moralidad. Los antiguos habrían buscado los fundamentos de la moral en estas causas naturales. Para unos -Diógenes, Rousseau- se nos darían naturalmente no habiendo necesidad de aprenderlas, para otros -Epicuro, Zenón, Hume- requerirían un aprendizaje y serían objeto de ciencia. Por contra, el ideal de santidad cristiano sería un ideal bueno en el sentido de que, como el propio Kant afirma, «el entendimiento debe a menudo luchar con las inclinaciones y aunque no podemos evitar estas sí que podemos evitar que determinen la voluntad». Pero más allá de estos tipos ideales, lo que Kant estaría buscando perfilar a través de esta sucesión de descartes teóricos no obedecería a ningún ideal sino a una idea, entendida esta «como un concepto necesario de la razón que, aun no teniendo como correlato un objeto en los sentidos, tiene un valor heurístico y regulativo». Más específicamente, una idea práctica entendida como un máximo o en palabras del propio filósofo, como «una perfección moral cuyo objeto nunca puede darse adecuadamente en la experiencia»y a la que le «corresponde que una acción suceda meramente a partir del concepto de deber sin ventaja ni provecho propio», es decir «una regla de conducta a la que siempre deberíamos acercarnos» según una ley de aproximación.

Llegado a este punto, Kant comienza a desarrollar esta idea de perfección moral ajena a los antiguos y a sus herederos. En base a ella la razón tiene suficiente capacidad para determinar la voluntad conforme a sus conceptos. Un ser con una natural buena voluntad no necesita de ningún imperativo y en este sentido en Dios ley objetiva y principios subjetivos o máximas coinciden de forma automática, de ahí que a Dios no se le presuponga deber alguno. Distinto es el caso del hombre cuya voluntad, lejos de ser naturalmente o por sí misma buena, está sujeta a inclinaciones y necesidades. Para que la razón devenga la ley objetiva determinante de la voluntad del hombre convirtiéndose en motivo de sus máximas, la ley subjetiva debe ser coaccionada. El imperativo de moralidad se da sólo allí donde existe una divergencia entre ley objetiva y ley subjetiva y tiene la forma de obligación, de mandato o prohibición, acciones por las cuales algo que antes no lo era, se vuelve ahora necesario. El imperativo de moralidad es, en suma, algo que se añade, la idea de una voluntad que actúa conforme a las leyes de la razón y que pauta nuestra voluntad. Representarnos cómo debemos actuar si la razón determinase enteramente nuestra voluntad abre un ámbito moral nuevo en el que, ignorando cualquier fin o propósito empírico, no se ordena bajo la condición de un fin real efectivo o posible, ya sea éste la 
felicidad o la utilidad. La necesidad propia al imperativo moral no está condicionada y por eso Kant lo califica de categórico; categórico por incondicionado. La voluntad del imperativo categórico es necesaria por corresponder a una ley objetivamente necesaria, pero no lo es subjetivamente para nosotros. Dirigiéndose a nuestra voluntad subjetivamente imperfecta, es decir, a nosotros seres humanos finitos y contingentes esa voluntad es necesitante y no necesaria. El «Normal Prinzip» del imperativo kantiano es el de que debemos realizar aquello que, tomado universalmente como regla, siempre pueda convertirse en objeto de la voluntad. La condición de su universalidad determina la voluntad del imperativo, es ella la que, de poder cumplirse, la transforma en una voluntad buena en sí misma y en toda circunstancia. Para que una máxima de nuestra voluntad pueda quedar subsumida en el imperativo categórico debe coincidir con su validez universal. Lo contrario a esta coincidencia son las acciones cuyas máximas sería imposible que las quisiéramos como regla universal: la mentira o el incumplimiento de promesas, por ejemplo, acciones que por más que subjetivamente posibles, no lo serían en tanto reglas de moral práctica ya que de implementarse universalmente o bien incurrirían en contradicción consigo mismas (imposibilidad moral condicionada que da lugar al deber imperfecto) o bien se suprimirían a sí mismas (imposibilidad moral incondicionada que da lugar al deber perfecto).

Enunciado el imperativo, las lecciones de Moral Mrongovius II seguirán desplegando penetrantes distingos y conceptualizaciones, que pasando por la diferencia entre precio y dignidad o entre vicio y virtud o entre omisión y comisión llegarán hasta el problema de la imputación, punto en que las lecciones se interrumpen. En este sentido, además de por el rico aparato de notas que la acompañan y por el excelente trabajo de traducción, esta edición bilingüe a cargo de la profesora Alba Jimenez destaca igualmente por el estudio conclusivo de que consta y en el que se acomete el trabajo de dar continuidad bajo una perspectiva crítica al problema kantiano de la imputación. Asimismo y también en dicho estudio conclusivo el lector encontrará un análisis de las líneas de tensión que atraviesan la fundamentación kantiana de la moral, cuyo proceso, si bien idealmente culminado en el modelo tripartito nouménico-teológico / moral / y fenómenico-patológico que la editora nos muestra en el ilustrativo cuadro sinóptico de la conclusión, no deja por ello de desarrollarse a lo largo del hilo rojo del dualismo kantiano entre ser y deber ser, ni deja de estar exento, por momentos en su corazón mismo, de «la intromisión ilegítima de justificaciones utilitaristas».

Por la erudición e inteligencia de la que prólogo, epílogo y aparato de notas dan testimonio así como por la excelencia de la traducción estamos, pues, ante una edición de las Lecciones de filosofía moral Mrongovius II de Kant cuya lectura se nos aparece fundamental, no ya solamente para estudiosos de Kant que deseen profundizar en la genealogía de los conceptos que están en su base, sino también para todos aquellos que menos familiarizados con la obra del filósofo alemán quieran acercarse a la misma de un modo desprejuiciado y no les importe, un poco a la manera como el propio K. C. Mrongovius debió de atender estas lecciones, situarse en un entramado de mediaciones en el que el factor coadyuvante de simultanear dos idiomas pueda añadirse a las múltiples que en el libro ya existen.

\section{Luis Javier Pedrazuela Idoeta}

